\title{
The Union Budget 2020-21: A Mixed Bag of Cheers and Tears
}

\author{
Anjali Tandon \\ Associate Professor, Institute for Studies in Industrial Development (ISID), New Delhi - 110070, India; \\ anjali.tandon.anjali@gmail.com
}

\section{Keywords: Disinvestment, Subsidy, Tax Reform, Un
JEL classification: E6, H6
1. Budget and its Perspective of the Economy}

A government budget is an exercise to meet the desired objectives, which are achieved through resource (re) allocations, incentives to various agents in the economy (e.g. tax concessions, reduced rates of borrowings for corporates and households), and constraints such as those on industry or consumers (e.g. caps on FDI in specific sectors). In an accounting sense, budget is an annual balance sheet of the government. It is different from a company balance sheet in the sense that it is an estimated statement of the economy-wide expenditures and revenues for the coming fiscal year. Through the annual budget, the government expresses its policy intent that (may) impact different agents in the economy. These agents could include individuals and business - both domestic and foreign (whether operating or willing to operate in India). Through its budget, the government also sends signals about its approach to drive the economy in a direction to achieve the objectives that the government has set for itself. These objectives are generally varied and broadly include economic growth and stability, and restructuring to address the disparities and inequalities across individuals (e.g. income categories, urban vis-a-vis rural, etc.), regions (e.g. between states) and business (e.g. public vis-a-vis private, large vis-a-vis medium and small sized firms, domestic vis-a-vis foreign owned firms, formal vis-a-vis informally organised firms). In India, the union budget for a fiscal year, e.g. 2020-21, is generally presented in the penultimate month of the preceding fiscal year i.e. 2019-20. If passed in the parliament, the budget proposals become effective from the beginning of the relevant fiscal period i.e. with effect from April 1, 2020.

In order to access the impact on the overall economy and the specific agents within, it is necessary to consider the budget as a mechanism to alter and improve the current economic conditions to achieve the targets, in addition to its merely being read as a financial statement of the government. This is important to understand the possible impacts a budget may have in the immediate future, which could also have a far reaching effect on growth conditions. For instance, an induced shift for lower savings, will immediately lead to higher consumption. However, lower savings will also limit funds available for investment. Much of the savings in India are intermediated by banks and non-banking financial institutes, both of which are key sources of investment. Consequently, decline in savings would impact negatively on the access to finance from the financial institutions, and have a constraining effect on long-term growth.

Thus, the budget should be viewed as short-term policy instrument of the government to achieve a long-term goal. Therefore, it becomes important to assess the budget proposals vis-a-vis the perspective it has set, and evaluate the steps towards achieving the specific goals. The latest Economic Survey (2019-20) released by the government has set the target for the economy at $\$ 5$ trillion, to be achieved by the year 2024-25. However, the first advance estimates for the year 2019-20 show an estimated GDP of $\$ 2.78$ trillion only. $\frac{1}{}$ This translates into a shortfall of $\$ 2.22$ trillion to be bridged over a period of next five years. This also means that with all the might that has been exercised since the economic reforms were launched in 1991, and the economic capacity that has been subsequently built through privatisation, liberalisation, restructuring and distributional attempts, the economy currently stands at $55.7 \%$ of the set target. Further, the budget 2020-21 has projected real economic growth at 6.5\% during 2020-21. This provides GDP estimates of \$2.96 trillion for the year, bridging the gap in achieving the $\$ 5$ trillion mark in a modest manner. 
While viewing the government's policy prescription through its budget, the present state of the economy is an important consideration. Presently, the economy is struggling through a slowdown that is non-cyclical in nature and rather has some structural attributes. First, the economy is seeking recovery from the twin shocks of demonetisation on November 8, 2016, immediately followed by the introduction of the GST on July 1,2017 . The period immediately following demonetisation was marked with reduction in 2-3\% reductions in jobs. 2 Labour force participation rates declined thereafter. Although the rate of decline has slowed down, the trends have continued with no signs of recovery. Factory investment also contracted in the immediately following period. The real estate sector has been among the worst hit sectors impacted by a limited cash supply, which forced many small developers to quit. The introduction of Goods and Services Tax (GST) increased compliance burden, particularly for the small business that were not friendly with an online interphase. This increased their operating costs. Even though small business within the threshold limit have been exempt form the requirement of a GST number, they lose out on clientage to bigger firms having GST registration, as the buyers seek GST numbers for credit against inputs. Second, the primary sector has been under crisis due to increasing farmer distress that has led many of them commit suicide. The famers' incomes have been locked at low levels for a long time with as many as $85 \%$ of farmers having monthly income levels of about Rs. 5000 per family (Ramanjaneyulu) ${ }^{2}$. The broad reasons for famer suicides, in addition to social factors, include vulnerability in the region, agrarian crisis, and lack of alternative opportunities (Padmanabhan and Dantewadia) ${ }^{10}$. Third, the financial sector also faces a structural problem with its persistent non-preforming assets (NPAs) that are only expected to rise further. The ratio of NPAs of the banks is much higher for state-run banks than for the private banks. Non-recovery of loan affects through further availability of funds for credit while also lowering the interest rates on bank deposits. Both these directly impact the investment and saving conditions in the economy.

The economic budget essentially drives the economy by controlling each of the three drivers of the economy, namely consumption, investment and external demand, through their response. Each of the three growth drivers has slowed down during 2019-20, thus emphasising their revival through policy stimulus (Figure 1).
In what follows, I discuss key policy measures as introduced in the Union Budget 2020-21.

\section{Macro Indicators in the Budget}

Essentially, the budget sets a target for three macro indicators - GDP growth, fiscal deficit, and revenue deficit in the reference. A 10\% GDP growth target has been set for 2020-21. Taking into account $4.5 \%$ inflation, this translates into 6.5\% real growth, higher than the 5\% real growth during 2019-20. The estimates of fiscal deficit at $3.5 \%$ of GDP and revenue deficit at $2.7 \%$ of GDP, in comparison to the corresponding values of $3.8 \%$ and $2.4 \%$ for 2019-20. Fiscal deficit is a measure of borrowings to meet expenses; revenue deficit refers to the shortfall in government earnings to meet its expenses for functions. A lower fiscal deficit shows lesser government borrowings; while a higher revenue deficit indicates that revenue shortfalls will be more than in the past.

However, the credibility of announcements can only be judged at least two years after their announcement, at a time when the actual expenditures and revenues realised are available with the government. This information will be available in the budget document of 2022-23 with a new set of issues before the policy makers to be addressed. .3 For illustration, budget of 2019-20 had set a disinvestment target of Rs. 1.05 lakh crore, while only Rs. 65,000 crores could be realised during the year with a staggering shortfall of $38 \%$ in the target. This was essentially because some of the big-ticket disinvestments such Air India could not materialise as there were no takers. Similarly, a tax revenue shortfall of $10 \%$ is noted vis-a-vis the budget estimate for the year 2018-19 for which the actuals are now available. The gap is essentially due to lower corporate tax collections as also the GST collections that were also much low.

The quality of fiscal deficit is as important as quantity. The proportion of revenue deficit in fiscal deficit is a measure of the quality of fiscal deficit. A lower revenue deficit-to-fiscal deficit ratio is favourable as it shows a lesser amount of fiscal deficit required to finance operations of the government. A lower proportion of revenue deficit implies that the scare financial resources are being used for capital expenditure to build capacity within the economy. The estimates for 2020-21 show an expansion in proportion of revenue deficit at the cost of a sliding share of capital expenditure. This implies that the government is using more than three-fourth of its 


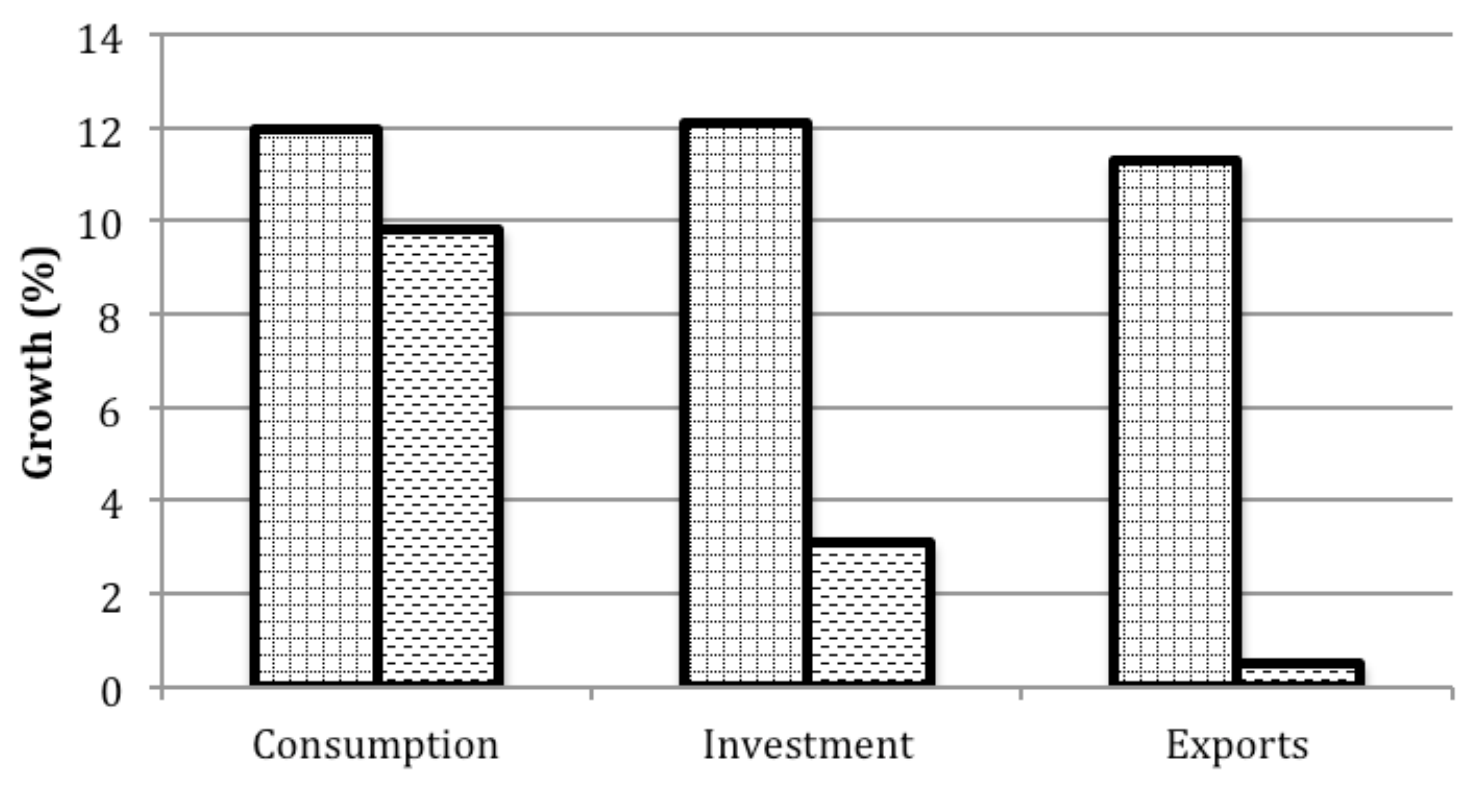

QTE 2018-19 $\mathbf{D}_{2019-20}$

Figure 1. Slowdown in Growth Drivers, 2019-20.

Note: Consumption includes both private and government consumption, investment refers to gross fixed capital formation. TE 2018-19 refers to the triennium average of growth rates during 2016-17, 2017-18 and 2018-19.

Figures for 2018-19 and ealier years are actual, for 2019-20 are revised estimates, for 2020-21 are budget estimates.

Source: Government of India, 2020a.

expenditure to finance its own operations such as payments towards salaries, interests and subsidies; while the capital expenditure makes a lower and declining proportion of total expenditure (Figure 2). Although the expansion in revenue deficit can be acceptable, if on account of social spending such as on health and education which will have productive gains in the long run, the lower allotment for capital expenditure is a concern in view of the crowding-in effect of government spending on private investment.

It should be noted that the estimated revenue deficit is wider after taking into account the projected expansion in non-tax revenue, essentially on the strength of anticipated telecom receipts, both Adjusted Gross Revenue (AGR) and the spectrum usage charges.

\section{Window Dressing of Fiscal Deficit}

The amount of food subsidy shows an absolute decline in the budget and revised estimates for 2019-20. However, it is misleading to conclude that the inefficiencies in the food procurement and distribution are being addressed. The food subsidy allocation in the revised estimate of 2019-20 has been lower by as much as $40 \%$. The absolute decline in food subsidy is even more unacceptable given the increasing liabilities from the National Food Security Act (NFSA) which provides highly subsidised food grains - wheat, rice and coarse cereals to more than 800 million beneficiaries at an insignificant issue price of Rs.3, 2 and 1 , respectively. The entire process of procurement at MSP, storage and distribution is managed by Food Corporation of India (FCI). Since FCI does not have revenue generation on its own, it is dependent on the government to make up for the difference between issue price and the MSP. In an attempt to keep the fiscal deficit low, the government tends to make short payments to FCI on account of transfers for subsidy and the operations of FCI. Therefore, FCI engages with other sources, e.g. National Small Saving Fund (NSSF), to meet its financial requirement through borrowing. The FCI uses the central transfers to meet its loan obligations to the NSSF and continues to borrow 
in successive years. This only keeps the rising subsidy in rotation, while camouflaging both, the continuation and increase in subsidy. This has been referred to as window dressing of fiscal deficit by some analysts (Gupta) ${ }^{\underline{7}}$. However, this is not the first instance where the NSSF has been used to finance loans to financially stressed PSUs such as the NHAI and Air India.

The vicious circle of continuously financing subsidy expenditures and issuing subsequent loans to refinance the past subsidy loans exposes NSSF collections to potential risks. The NSSF was constituted in 1999 to pool all collections from small savings such as the PPF, saving deposits and saving certificates. These savings are used to finance the withdrawals of the depositors while the balance is invested in special securities of the state and central government as decided from time to time. The pressure on NSSF places greater demand for deposits under different saving schemes. However, the proposed tax reform for individuals is a step-in the opposite direction with the individuals being dis-incentivised to invest in savings in exchange of a lower rate of income tax. Ultimately, small savings will be under strain, resulting in increased rate of interests to draw them back. Higher interest rate will in turn limit finance options, which will ultimately reflect through lower retail borrowings and resulting lower consumption of goods such as automobiles, electronics, and consumer durables, impacting growth prospects in the medium to long term.

\subsection{The Fear of Automatic Monetisation of Fiscal Deficit}

A weaker growth would trigger a wider than estimate fiscal deficit. Under such circumstance the government may resort invoking the 'escape clause' of the Fiscal Responsibility and Budget Management (FRBM) Amendment act. The escape clause allows breaching the fiscal deficit target by $0.5 \%$ of the GDP, under conditions of severe stress. The conditions could be due to structural crisis such as in the case of an oil price shock or a trade war that can significantly lower export incomes for domestic producers; acts of war or national calamities, or if the real output contracts at least $3 \%$ points below the average of four preceding quarters. A broad implication of

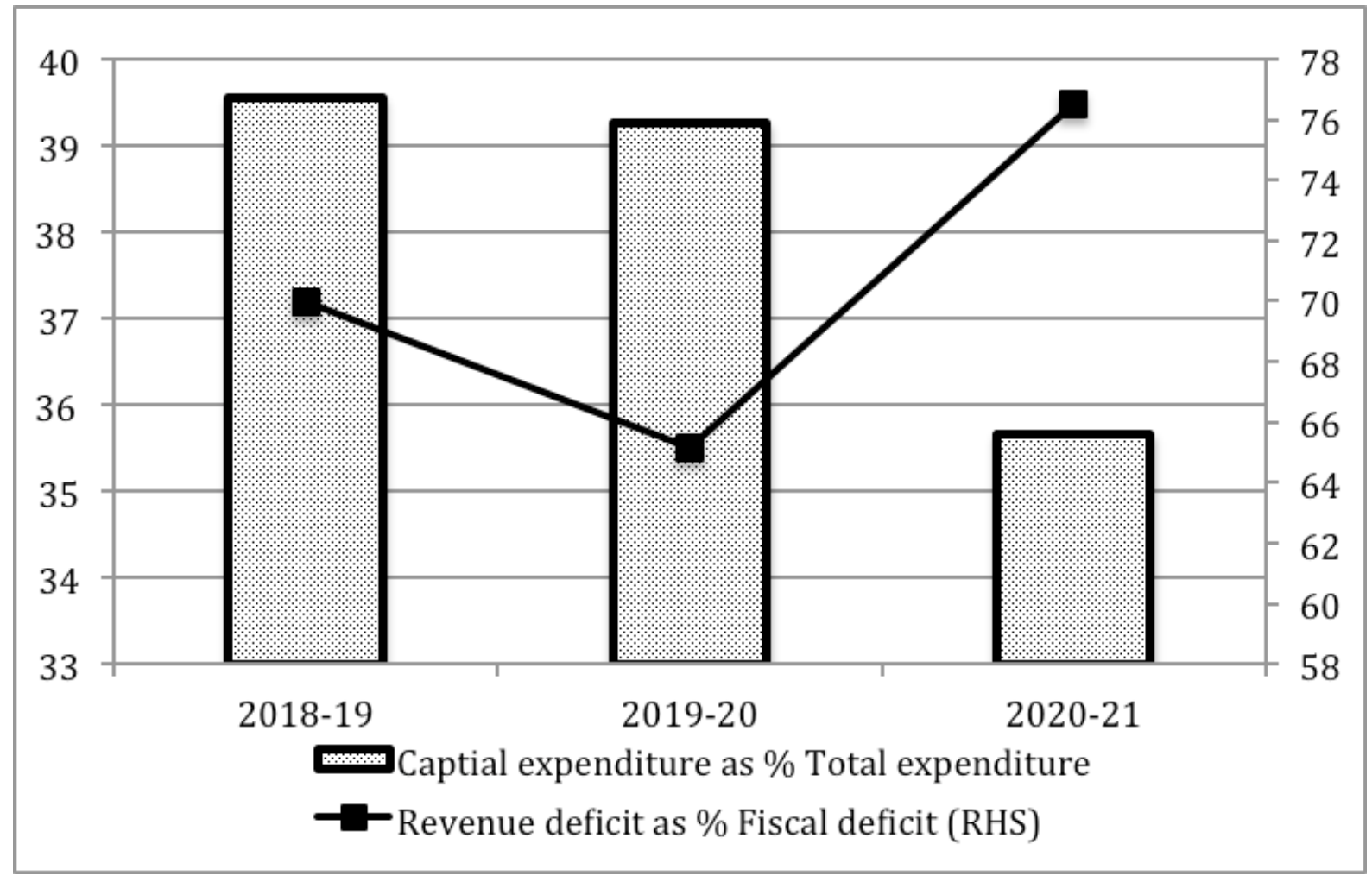

Figure 2. Quality of Fiscal Deficit.

Note: Figures for 2018-19 are actual, for 2019-20 are revised estimates, for 2020-21 are budget estimates.

Source: Government of India, 2020b. 
exercising the escape clause in responding to an overshoot in fiscal deficit is implicit deficit financing. If continued to practice, this will actually take the economy back to the era of FRBM Act 2003 that has been abandoned in past where the government would issue bonds to finance the deficit and the RBI would subscribe to same. During 2019-20 the escape clause was revoked to relax the fiscal deficit target of $3.3 \%$ to the revised target of $3.8 \%$. Likewise, it is speculated that under current slowdown the fiscal deficit target of $3.5 \%$ will have to be stretched by 0.5 percentage points to $4 \%$ under the conditions of a real growth of 6-6.5\%. In view of the fiscal targets of 3.3\% and $3.1 \%$ for 20201-22 and 2022-23, the target of $3 \%$ fiscal deficit seems far from reach in next few years.

\subsection{Expenditure on Subsidies and Schemes}

\subsubsection{Subsidy Allocations}

The total expenditure on subsidies is estimated to be lower by $0.5 \%$ during $2020-19$, in comparison to the revised estimate figures for the 2019-20. Much of the decline is on account of fertiliser subsidy allocation and 'other' subsidies inclusive of interest subsidies for various schemes, subsides for price support for agricultural produce, and for assistance to states agencies for procurement (Figure 3).

\subsubsection{Consumption Effect of Outlay on Schemes}

The details of expenditure during the year are declared under various schemes that are broadly categories into (i) Core of the Core $(\mathrm{CoC})$ schemes, (ii) Core schemes, and (iii) Major central sector schemes. These collectively constitute the centrally sponsored schemes that are jointly financed by the centre and states, with a larger contribution from the centre. Through the execution of $\mathrm{CoC}$ schemes, the government prioritises on its national development agenda by following social security measures and social inclusion. Of the total scheme expenditure of Rs 11.72 lakh crore, the allocations under the above three is Rs. 0.85 lakh crore, Rs. 2.55 lakh crore and Rs. 3.40 lakh crore, respectively. Out of the six CoC schemes, allocations for three of the flagship programmes have declined both in absolute term as well as proportionately (Table 1). ${ }^{4}$ A lower allocation for the National Social Assistance Program, which includes social benefits such as old age pension, disability allowance, and pension for the widows,

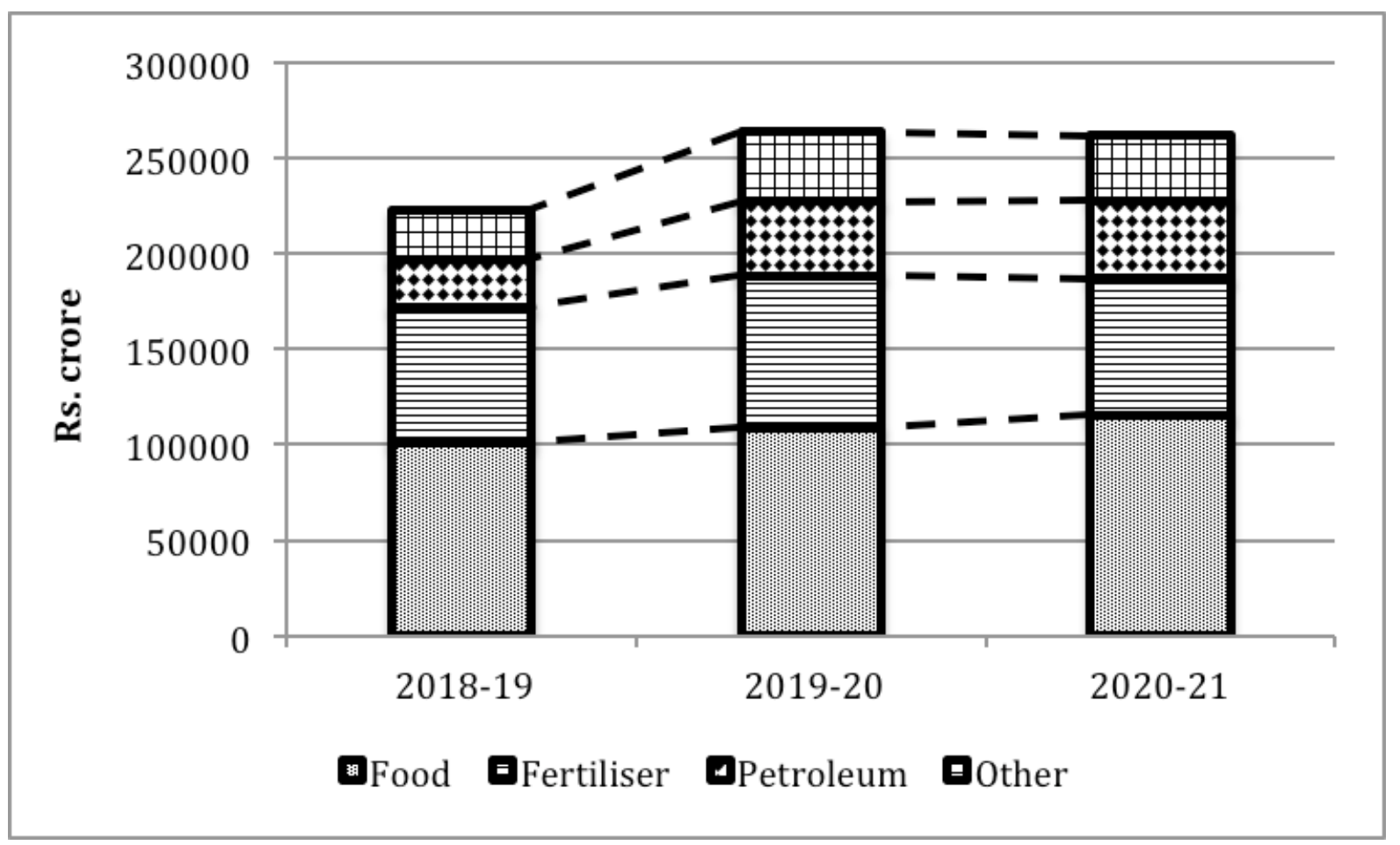

Figure 3. Distribution of Subsidy Allocations.

Note: Figures for 2018-19 are actual, for 2019-20 are revised estimates, for 2020-21 are budget estimates. Source: Government of India, 2020b. 
will hurt the beneficiaries. Similarly, lower allocation for Mahatma Gandhi National Rural Employment Guarantee Programme will have an impact on programmes for rural development. Many have argued that greater allocation for the programme under MGNREGA could have helped rural employment during the current slowdown, by generating income opportunities, ultimately encouraging demand spending, in turn helping achieve better growth. Since MNEREGA beneficiaries belong to low-income quartiles in the economy, where the multiplier effects of income on consumption are much higher in the economy, the lower allocation is undesirable. Likewise, there is a lower allocation for the Umbrella Programme for Development of Scheduled Tribes.

Similarly, there are 23 core schemes of the government through which the allocation has emphasised on development of the agriculture sector. Allocation under green, white and blue revolutions have increased along with the budgeted amounts for irrigation facilities (Table 2). This is in contrast to a lower allocation under the National Health Mission (NHM), where the budgeted amount has declined in absolute term, as well as a percentage of the GDP, reflecting a much lower share in the overall allocations for the core schemes of the government. The contraction in NHM spending will constrain health care facilities. Although there has been emphasises on development of physical infrastructure, the needs for softinfrastructure have remained unattended. For instance, the doctor-patient and nurse-patient ratios are too low to be bridged immediately. However, a balancing has been attempted through greater allocation for the Ayushman Bharat scheme that provides health insurance, indicating a greater emphasis on insurance provisions over health services within the public sector set-up. Similar is the case for allocation for the job and skill development schemes where a contraction is noted both in absolute and relative terms. Allocations under National Education Mission have also declined in relative terms, both as percentage of GDP and as a proportion of the total allocation for the core schemes during 2020-21; Rs. 99,300 crores have been budgeted for higher education. The increase of $5 \%$ over last year effectively nullifies the $4.5 \%$ inflation estimate

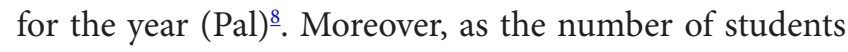
expands every year (demographic advantage), the spending per student would actually decline. Allocations for school and college scholarships have also declined by

Table 1. Expenditure on Core of the Core Schemes

\begin{tabular}{|c|c|c|c|c|c|c|c|c|}
\hline & & \multicolumn{2}{|c|}{ Outlay (Rs. crore) } & \multicolumn{2}{|c|}{ Outlay as \% of GDP } & \multirow{2}{*}{$\begin{array}{l}\text { Growth of outlay (\%) } \\
2020-21 \text { over } 2019-20\end{array}$} & \multicolumn{2}{|c|}{$\begin{array}{l}\text { Share in allocation } \\
\text { under the scheme (\%) }\end{array}$} \\
\hline & & $2019-20$ & $2020-21$ & 2019-20 & $2020-21$ & & 2019-20 & $2020-21$ \\
\hline 1 & $\begin{array}{l}\text { National Social Assistance } \\
\text { Program }\end{array}$ & 9200 & 9197 & 0.045 & 0.042 & -0.03 & 9.8 & 10.8 \\
\hline 2 & $\begin{array}{l}\text { Mahatma Gandhi National } \\
\text { Rural Employment } \\
\text { Guarantee Program }\end{array}$ & 71002 & 61500 & 0.347 & 0.282 & -13.38 & 75.9 & 72.2 \\
\hline 3 & $\begin{array}{l}\text { Umbrella Scheme for } \\
\text { Development of Schedule } \\
\text { Castes }\end{array}$ & 5568 & 6242 & 0.027 & 0.029 & 12.10 & 6.0 & 7.3 \\
\hline 4 & $\begin{array}{l}\text { Umbrella Programme for } \\
\text { Development of Scheduled } \\
\text { Tribes }\end{array}$ & 4194 & 4191 & 0.021 & 0.019 & -0.07 & 4.5 & 4.9 \\
\hline 5 & $\begin{array}{l}\text { Umbrella Programme for } \\
\text { Development of Minorities }\end{array}$ & 1709 & 1820 & 0.008 & 0.008 & 6.50 & 1.8 & 2.1 \\
\hline 6 & $\begin{array}{l}\text { Umbrella Programme for } \\
\text { Development of Other } \\
\text { Vulnerable Groups }\end{array}$ & 1846 & 2210 & 0.009 & 0.010 & 19.72 & 2.0 & 2.6 \\
\hline & Total of the above & 93519 & 85160 & 0.457 & 0.391 & -8.94 & 100.0 & 100.0 \\
\hline
\end{tabular}

Note: Figures for 2019-20 are revised estimates, for 2020-21 are budget estimates.

Source: Government of India, 2020b. 
Table 2. Expenditure on Core Schemes

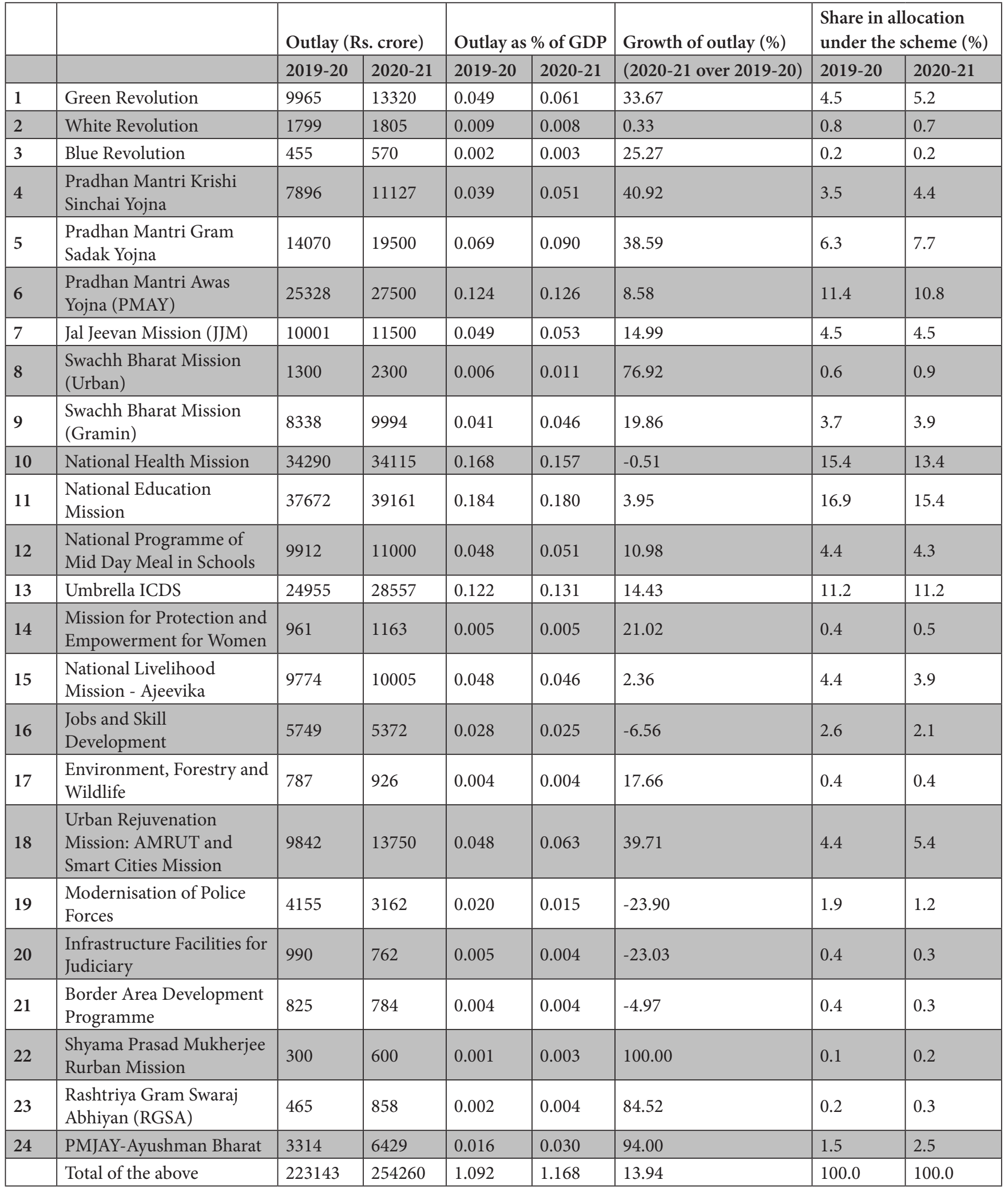

Note: Figures for 2019-20 are revised estimates, for 2020-21 are budget estimates.

Source: Government of India, 2020b. 
$60 \%$ this year. The schemes, which have benefitted most from these additional allocations for year, are related to agriculture, development of urban smart cities and child development.

A large number of major central sector schemes are indication of a granular structure of the schemes, which are often criticised for being too many and not necessarily mutually exclusive. ${ }^{6}$ Emphasis has been put on R\&D activities as noted from increased spending on Research and Development; Innovation, Technology Development; and R and D in IT/Electronics/CCBT. Similar boost has been given to infrastructure development and capacity building programme. Lower expenditure as a percentage of GDP is noted under skill development and livelihoods as also for the higher education financing agency. Similar allocations for women development schemes, such as Beti Bachao Beti Padhao, and Ujjawala schemes have declined (Chaudhuri, 2020). Although allocations for PM-KISAN have increased under the KCC, but this is likely to not have a significant impact due to limited access of $27 \%$ of the eligible farmers, probably pushing further the goal of doubling famers' income by 2020 (Pal, 2020).

Sectors such as road and highways infrastructure received greater allocations. Privatisation of railways through running private trains may be a second best option to having a private coach in each train (Bhattacharya, 2020). The latter arrangement would inculcate a spirit of competition while also benefitting the public operator through spillovers.

The government envisions a huge potential for export of education services through permitting Top 100 institutes for online degree courses. Perhaps, the opportunity is anticipated, learning from the successful e-commerce models and online banking facilities in contrast to the conventional brick \& mortar model of banking in branches.

The allocations for schemes directly impacting performance in external sector has been mixed. Budget for EXIM Bank has been reduced, and investment in the Export Credit Guarantee Corporation (ECGC) has also reduced a percentage of GDP. The latter is in view of the recent challenges to the scheme at the WTO. Subsequently, the government has announced a stimulus package for export credit under the NIRVIK (Niryat Rin Vikas Yojana) Yojana.

To summarise the expenditure allocations, emphasis on insurance provisions has increased both in the agriculture and health sector. A clear policy stimulus for employment and consequent income generation to encourage domestic consumption in the lower income quartiles is not seen from the expenditure allocations.

\subsection{Reform on Personal Income Tax}

A major change in the budget is introduction of a choicebased tax structure, with and without tax exemptions. In the past, tax incentives have been used to incentivise individual savings. For instance, an earlier work has shown that increasing the PPF limits by Rs. 50,000 in 2014 resulted in drawing-in many more investments from individuals in the age groups of 56 year and those above 75 years (Ghosh and Ghosh, 2020). At the same time, investors belonging to lowest income quartiles increased the frequency of deposits expressing their willingness to save more. Simultaneously, other factors that support household savings per capita include real income, dependency ratio, inflation, and real interest rates. The household savings are positively impacted by real income indicating the inclination to save more as income expands. The behaviour can be attributed to greater savings needed to meet expenses during life after superannuation, as longevity has improved over time. Individuals with higher dependency ratio, whether of children or elderly in the family, are likely to invest in savings to meet for their future expenses. Rise in inflation pushes the investor to dis-save in order to maintain the standard of living. Rising real interest rates improve the prospects of higher lifetime income, thereby encouraging a consumption based spending resulting in lower savings. Also, other features such as, access to bank branches tends to have a positive effect on individual savings. However, the potential beneficiaries of switching to the deduction free tax structure are the workers who have not availed the benefits of tax exemptions on housing loans. Since most of such workers are at the low-income qualities and belong to unorganized sector, the reform is unlikely to generate sweeping shifts. Further, even if the individual shifts to the new taxation structure, this may not immediately stimulate consumption in an environment of limited social security. Also, shifting to new tax structure by surrendering the tax benefits on housing loans could be hard hitting for the construction and real sector due to low demand. However, the decision to opt for a specific tax structure has been left to the individual. Nevertheless, this has created confusion and increased computational efforts (as an individual will compute tax liabilities under both cases to make a chose) at a time 
when there has been increasing emphasis on simplifying business procedures.

\subsection{Corporate Tax Reform}

The abolishing of Dividend Distribution Tax (DDT) is another major tax related measure introduced in the budget. This is an attempt to eliminate the tax cascading on inter-corporate dividend. For instance, dividend distributed by an Indian subsidiary of an MNC was earlier taxed as per the DDT in India. However, the parent country, e.g.US, did not exempt the MNC for deductions against the DDT paid in India. This resulted in additional tax burden in the country of jurisdiction. Earlier DDT of $15 \%$ with a surcharge and cess effectively amounting to another $20.5 \%$ topped with $25 \%$ corporate tax; resulted in about $46 \%$ tax rate for the corporates. This was much higher than what the stakeholders were paying on their individual income. Under the new set-up the DDT is now taxable for the beneficiary i.e. individual.

The increase in individual tax liability is expected to disincentivise non-institutional investors to sell their shares in favour of corporate buybacks. This will result in greater resources in the corporate kitty. Consequently, a greater proportion of profit retention in the corporates will be ploughed back to increase capacity and improve capacity utilisation measures through technological advancements. This will ultimately improve supply dimensions of the economy, eventually supporting the consumer through lower prices.

\subsection{Unrealistic Disinvestment Targets}

The government is riding an ambitious disinvestment plan of Rs. 2.1 lakh crore to be realised during 2020-21. Having missed the disinvestment target of Rs. 1.05 lakh crore for 2019-20 with a shortfall of $38 \%$, the targets have been set enormously higher at $223 \%$ of the realised value in 2019 20. The government has placed LIC for disinvestment. However, the market response is uncertain on the LIC in disinvestment, which also has unserviced loans of very high order. It has bad loans adding to Rs 30,000 crore with Bhushan power, Deccan Chronicle, Essar Port, Gammon, IL\&FS, Unitech and Videocon Industries as major defaulters. At least 18 of the 21 banks that have borrowed from LIC are running losses. So, the investors' reaction cannot be predicted immediately. Moreover, the floating of the IPO itself can take sometime, making the disinvestment target difficult to materialise within the year.

The performance of PSU is of importance, which cannot be discounted, especially during the crisis period or times of low growth. The role of PSUs cannot be overstated as driver of demand from consumption of various inputs. Moreover, the presence of a well functioning public sector has a crowding-in effect on private investors. Therefore, complete dis-investment in PSUs may not be an optimal solution. Instead, efforts to improve the performance of PSU would be more fruitful for the PSU, corresponding sector and the overall economy.

\subsection{Incentives for Entrepreneurs}

The start-ups have been facilitated by deferring the tax payments on Employee Stock Options (ESOPs) upto 5 years, or at the time of sale or exit, whichever is earlier. Earlier the ESOPs were taxable at the time of allotment. The turnover limits for an eligible start-up to available $100 \%$ deduction of profits for three consecutive years has been increased from Rs. 25 crore to Rs. 100 crore. Further, the profit deduction can now be exercised over a period of first 10 years as compared with the earlier shorter duration of seven years.

However, the tax benefits are believed to have limited scope of application. The benefits are applicable only for companies qualifying under the Section 80-1AC, thus contrasting the benefit to only 200 of the 27000 start-ups that have been formed after 2016, and are also recognised by the inter-ministerial board. This prevents the older start-ups from benefitting from the move.

In a move to encourage and sustain Micro, Small and Medium Enterprises (MSMEs), the restructuring scheme has been extended upto March 2021. The national logistic policy is expected to improve competitiveness of the MSMEs. The proposed amendment to enable invoice financing of MSMEs from NBFCs will improve their access to finance.

\section{Measures to Revive External Sector}

During the period of slowdown, revival of external sector is both critical and difficult for the domestic economy. It is said that the exports need to touch $\$ 1$ trillion if the $\$ 5$ trillion target for the economy is to be achieved. However, the export growth in the past one-year has been nearly 
flat (refer Figure 1). Moreover, the existing investment in export credit guarantee scheme has been cut down notably. Similarly, the allocation for EXIM bank has also been slashed. The move is perhaps in view of design of alternate programmes to support exporters, since the existing programmes have been challenged in the WTO. As stimulus package has been announced for export credit through the Niryat Rin Vikas Yojna (NIRVIK). The NIRVIK scheme provides higher export credit disbursement of the principal and interest of up to $90 \%$ of the amount through higher insurance cover. Additionally, the small exporters would benefit from reduced premiums. Further, simplified procedures for claims are also expected to improve competitiveness of exporters through increasing time efficiency in procedural norms. The scheme also has provisions for reimbursement of state levies for the exporters on account of their input costs towards use of electricity. This measure is designed in recognition of its WTO compliance. However, such measures will be effective only if their executive is not cumbersome and easier for the claimant.

On the other hand, the government has exercised higher protectionism compared with recent past. Custom tariffs have been imposed/ increased to encourage import substitution, or on grounds of safeguard measures and tariff quotas for protection from injury to domestic industry. The protectionist measure takes us back to the pre-reform period where the domestic industry thrived in a protected environment and looked for government support. Instead, measures to make the industry compete with world standards would have helped in long-term prosperity of the Indian exporters of goods. These products include many labour intensive light manufactured products such as household items (e.g. tableware, kitchenware, glassware) and appliances (e.g. fans, grinders) and footwear, toys, specified stationary items, among others. The basic custom duty rates in some cases has been doubled or tripled.

Also, a health cess has been introduced on import of medical devices under specified categories such as X-ray machines. The cess will be utilised for development of health infrastructure and services. Social welfare changes have been amended for import of electronic devices. The increased cost of import will be passed to the consumer as custom duties amount to cost push inflation, disregarding the Ricardian theory of comparative advantage. The move seems to disagree and adjourn the view to set our own house in order by providing a conducive ecosystem to manufacturers of all sizes.

\section{Summing-up}

To wrap it up, the Budget 2020-21 can be considered as transitional in nature as it seems to direct money flows to business through reforms on corporate tax. Apparently, the government is commanding a model of investment driven economic growth for long-term sustainability. However, under current crisis with regard to jobs, unemployment, demand depression and low consumption, the economy requires immediate stimulus package, which is absent in the budget. There seems to be an attempt to energise consumption through tax benefits on dis-saving. This however dis-regards the link between savings and consumption, as the former are used to finance consumer durables such as cars, electronics and real estate purchase. The importance of savings cannot be overstated in an economy where there are no provisions for universal healthcare, social security, and unemployment allowances.

\section{References}

1. Bhattacharya K. Economists Speak 2020 India Union Budget. The Edition. 2000; 9 Feb. https://intheedition. wordpress.com/2020/02/09/e-c-o-n-o-m-i-s-t-s-s-p-e-ak-2020-india-union-budget/?fbclid=IwAR2NiDExSL5R PHZCZWdBhYYGGS8TGh5EObzOySiiWO4gp5EueE_ Tq5HK_3Q

2. Business Standard. Demonetisation, 3 years on: A look at impact on key sectors of the economy. 2019; 8 Nov. https:// www.business-standard.com/article/economy-policy/ demonetisation-3-years-on-a-look-at-impact-on-key-sectors-of-the-economy-119110701482_1.html

3. Chaudhuri L. Economists Speak 2020 India Union Budget. The Edition. 2020; 9 Feb. https://intheedition.wordpress. com/2020/02/09/e-c-o-n-o-m-i-s-t-s-s-p-e-a-k-2020-india-union-budget/?fbclid=IwAR2NiDExSL5RPHZCZWdB hYYGGS8TGh5EObzOySiiWO4gp5EueE_Tq5HK_3Q

4. Ghosh SK, Ghosh P. The Determinants of Household Savings in India. Business Standard. 2020; 12 Feb.

5. Government of India. Economic Survey 2019-20. Department of Economic Affairs, Economic Division, Ministry of Finance. 2020a.

6. Government of India. Union Budget 2020-2021, Ministry of Finance. 2020b. 
7. Gupta U. Drastic cut in food subsidy - real or fudged. 2020; 7 Feb. https://www.uttamgupta.com/agriculture-foodgrain/ drastic-cut-food-subsidy-real-fudged/

8. Pal S. Economists Speak 2020 India Union Budge. The Edition. 2020; 9 Feb. https://intheedition.wordpress. com/2020/02/09/e-c-o-n-o-m-i-s-t-s-s-p-e-a-k-2020-india-union-budget/?fbclid=IwAR2NiDExSL5RPHZCZWdB hYYGGS8TGh5EObzOySiiWO4gp5EueE_Tq5HK_3Q

9. Ramanjaneyulu GV. A Perspective on the Agricultural Crisis in India (Part 1). F. Athar. 2019; 10 June. https:// indiabioscience.org/columns/conversations/a-perspectiveon-the-agricultural-crisis-in-india-

10. Padmanabhan V, Dantewadia P. The Geography of Farmer Suicide. LiveMint. 2020. 16 Jan. https://www. livemint.com/news/india/the-geography-of-farmersuicides-11579108457012.html

\section{Notes}

${ }^{1}$ Considering an exchange rate of INR 73.43 per $\$$ as on 4 March 2020

${ }^{2}$ As reported in Business Standard, November 8, 2019.

${ }^{3}$ For example, the budget 2020-21 provides budget estimates (BE) for the reference fiscal year (2020-21), revised estimates (RE) for the ongoing fiscal (2019-20), and actuals for the earlier year (2018-19).

${ }^{4}$ Refers to the allocation under the scheme as a percentage of GDP.

${ }^{5}$ MNREGA refers to Mahatma Gandhi National Rural Employment Guarantee Act.

${ }^{6}$ There are 86 major central sector schemes. 